\section{The role of ecto-nucleotide pyrophosphatase/phosphodiesterase 1 in diabetic nephropathy}

\author{
Papel da ectonucleotídeo pirofosfatase/fosfodiesterase \\ 1 (ENPP1) na nefropatia diabética
}

Denise Alves Sortica ${ }^{1,2}$, Daisy Crispim ${ }^{1,2}$, Guilherme Pozueco Zaffari ${ }^{1,2}$, Rogério Friedman ${ }^{1,2}$, Luis Henrique Canani ${ }^{1,2}$

\section{SUMMARY}

The increased prevalence of diabetes mellitus has caused a rise in the occurrence of its chronic complications, such as diabetic nephropathy (DN), which is associated with elevated morbidity and mortality. Familial aggregation studies have demonstrated that besides the known environmental risk factors, DN has a major genetic component. Therefore, it is necessary to identify genes associated with risk for or protection against DN. Ecto-nucleotide pyrophosphatase/phosphodiesterase 1 (ENPP1) is expressed in several tissues, including the kidneys. Increased levels of ENPP1 expression inhibit tyrosine-kinase activity of the insulin receptor in several cell types, leading to insulin resistance. K1210 polymorphism of the ENPP1 gene seems to be associated with insulin resistance and DN development. The elucidation of genetic factors and their associations will provide better understanding of the pathogenesis of DN and, may consequently, lead to a more effective approach to prevention and treatment. Arq Bras Endocrinol Metab. 2011;55(9):677-85

\section{Keywords}

ENPP1; diabetic nephropathy; diabetes mellitus; DNA polymorphisms; chronic renal disease; insulin resistance

\section{SUMÁRIO}

A crescente prevalência do diabetes melito tem causado aumento na ocorrência das suas complicações crônicas, como a nefropatia diabética (ND), a qual está associada com elevada morbidade e mortalidade. Estudos de agregação familiar demonstram que a ND tem um importante componente genético, além dos conhecidos fatores de risco ambientais. Portanto, existe a necessidade de se identificarem genes associados ao risco ou proteção à ND. A ectonucleotide pyrophosphatase/phosphodiesterase 1 (ENPP1) é expressa em vários tecidos, incluindo nos rins. Foi encontrado que níveis aumentados de expressão da ENPP1 inibem a atividade tirosino-quinase do receptor da insulina em vários tipos celulares, causando resistência à insulina. 0 polimorfismo K1210 do gene ENNP1 parece estar associado com resistência à insulina e com o desenvolvimento da ND. A elucidação dos fatores genéticos e de suas associações permitirá um melhor entendimento da patogênese da ND e, consequentemente, poderemos ter uma abordagem mais efetiva em sua prevenção e tratamento. Arq Bras Endocrinol Metab. 2011;55(9):677-85

Descritores

ENPP1; nefropatia diabética; diabetes melito; polimorfismos de DNA; doença renal crônica; resistência à insulina
${ }^{1}$ Endocrinology Service, Hospital de Clínicas de Porto Alegre, Porto Alegre, RS, Brazil ${ }^{2}$ Graduate Program in Medical Sciences, Endocrinology, Universidade Federal do Rio Grande do Sul (UFRGS), Porto Alegre, RS, Brazil
Correspondence to: Luis Henrique Canani Rua Ramiro Barcelos, 2350 prédio $12,4^{\circ}$ andar 90035-003 - Porto Alegre, RS, Brazil

Received on 1/June/2011 Accepted on 26/Nov2011

\section{INTRODUCTION}

D iabetes mellitus (DM) is characterized by chronic hyperglycemia resulting from defects in both insulin secretion and action (1). Depending on the intensity and time of exposure to hyperglycemia, structural lesions can occur in the vascular endothelium and neuronal tissue, leading to the onset of diabetic chronic complications and, ultimately, causing dysfunction and failure of several organs and tissues. These complications can be divided into microangiopathic and macroangiopathic, and they are the most common causes of morbidity and mortality in diabetic patients. Among 
the most important diabetic chronic complications is diabetic nephropathy (DN) (1).

\section{DIABETIC NEPHROPATHY (DN)}

Chronic kidney disease (CKD) is defined as kidney damage resulting from structural or functional abnormalities of the kidneys, or by glomerular filtration rate (GFR) < $60 \mathrm{ml} / \mathrm{min} / 1.73 \mathrm{~m}^{2}$, with or without structural kidney damage, for a period of 3 months or more, independent of cause (2). DN is the main cause of kidney disease in patients entering dialysis programs (2). Traditionally, DN is characterized by physiopathological changes resulting from the diabetic milieu, which begin with glomerular hyperfiltration and kidney hypertrophy, and tend to progress to proteinuria and progressive GFR reduction (2). Hyperglycemia, elevated blood pressure levels and genetic predisposition are major risk factors for DN $(2,3)$. In addition, elevated levels of serum lipids, smoking, and the amount and source of dietary protein also appear to be risk factors for developing DN (2).

$\mathrm{DN}$ incipient stage is characterized by a small increase in urinary protein excretion, mainly albumin. This small amount of protein (known as microalbuminuria) is not detected by total urinary protein measurements. Only very sensitive tests (immunoassays or HPLC techniques) are able to detect these small amounts of albu$\min$ in urine. The alteration may be present at any time in DM, but is more frequently detected after at least five years of disease evolution. The evolution of microalbuminuria is very variable. Without intervention in patients with type $1 \mathrm{DM}$, microalbuminuria can evolve to clinical proteinuria (or macroalbuminuria) over a period of approximately 10 years. It is only then that conventional urine tests begin to detect the alteration. During microalbuminuria stage, no change in GFR is expected, but a progressive decline in GFR occurs in the proteinuric phase, which may ultimately evolve to end-stage renal disease (ESRD) within another 10 years (4). However, more recent knowledge suggests that this progression is not so well-defined. About one third of subjects with microalbuminuria will spontaneously regress to normoalbuminuria, and approximately the same proportion will remain stable in the microalbuminuria stage (5). It is also known that a proportion of subjects will present reduced GFR in the absence of increased urinary albuminuria (6).

DN affects around $30 \%$ of diabetic patients and is responsible for over a third of new cases of kidney failure in individuals entering dialysis programs. It is associated with a major increase in mortality, mainly from cardiovascular causes (7). Bruno and Gross (8) followed up 111 diabetic patients beginning dialysis at different centers for an average 3.6 years, and observed that $\mathrm{DN}$ was the primary kidney disease in $61 \%$ of the cases. The mean survival rate in the $1^{\text {st }}, 2^{\text {nd }}$ and $3^{\text {rd }}$ year of follow-up was $69 \%, 51 \%$ and $28 \%$, respectively. Macrovascular complications were the main predictors of mortality in this cohort, and cardiovascular disease was the main cause of death ( $63 \%$ of the cases) (8).

Between 25 and $40 \%$ of type 1 DM patients develop $\mathrm{DN}$ after 25 years of disease, and DN is the main cause of death in these patients (9). The cumulative incidence of microalbuminuria in type $1 \mathrm{DM}$ patients was $12.6 \%$ in a 7.3 years follow-up, according to The European Diabetes (EURODIAB) Prospective Complications Study Group (10). Proteinuria or macroalbuminuria occur in $15 \%$ to $40 \%$ of type $1 \mathrm{DM}$ patients, with a peak incidence at $15-20$ years of DM (11). In type $2 \mathrm{DM}$, up to $33 \%$ of patients presented DN after an 18-year follow-up, in a Danish study (12). In patients with type $2 \mathrm{DM}$, the prevalence of $\mathrm{DN}$ varies from $20 \%$ to $50 \%$, depending on the ethnic origin (12). The anual incidence of proteinuria was $2.0 \%$, and the prevalence after 10 years of type $2 \mathrm{DM}$ diagnosis was $25 \%$ in the UK Prospective Diabetes Study (UKPDS) cohorts (13). The prevalence of proteinuria can vary between $5 \%$ to $20 \%$ (13).

\section{GENETICS OF THE DIABETIC NEPHROPATHY}

Familial aggregation studies show major agreement for the development of DN in some families, strengthening the hypothesis that there are genetic factors involved in its pathogenesis (14). Diabetic patients who have relatives with both DM and DN present a significantly greater risk of developing renal disease compared with diabetic patients who have no relatives with this complication $(14,15)$. Epidemiological data indicate that there is a genetic susceptibility to the development of $\mathrm{DN}$, because the incidence peaks between 15 and 20 years after the diagnosis of DM, and then declines rapidly, resulting in a cumulative incidence of less than $30 \%$ (16). If $\mathrm{DN}$ were caused only by hyperglycemia, its incidence would increase progressively over time, and most diabetic patients would develop renal disease, similar to what happens with diabetic retinopathy (17).

Furthermore, patients with DM and DN present a family history of arterial hypertension and cardiovas- 
cular disease (CVD) more often than diabetic patients without DN (18). The presence of microalbuminuria is a strong predictor of death by CVD, possibly even stronger than it predicts the development of more severe forms of $\mathrm{DN}(12,19)$.

Therefore, it is necessary to identify genes that may predispose to the development and progression of kidney disease, as well as genes that may be associated with protection against this complication.

It has been estimated that the human genome contains about 25,000 genes and more than 10 million genetic polymorphisms (20). The development of a complex disease such as DN depends on the effect of many genetic variables acting synergistically and additively with each other and with environmental factors (21).

There are several ways of studying the role of genes in relation to DN susceptibility (20). An often used strategy is the candidate gene approach (22). Among the different studies that have evaluated the role of genetics in DN using this approach, we will focus on those related to gene ENPPI.

\section{ECTO-NUCLEOTIDE PYROPHOSPHATASE/ PHOSPHODIESTERASE 1 (ENPP1) PROTEIN AND INSULIN RESISTANCE}

ENPPl (ecto-nucleotide pyrophosphatase/phosphodiesterase 1 ) is one of the five cell-membrane proteins containing an active extracellular site which catalyzes the release of nucleoside-5-phosphatase from nucleotides and their products. These proteins consist of a short terminal $\mathrm{NH}_{2}$ intracellular domain, a single transmembrane domain, two somatomedin-B-like domains, and one $\mathrm{COOH}$-terminal nuclease-like domain (23). ENPPl is a 230-260 kDa homodimer, and its reduced form has a molecular size of $115-135 \mathrm{kDa}$, depending on the cell type (24). Human ENPP1 has 873 aminoacids (24).

It is known that ENPPl is expressed in several tissues, including skeletal tissue, adipose tissue, and liver and kidneys (24). However, the physiological functions of ENPPl in these tissues have not yet been fully described. It is also expressed, in smaller amounts, in pancreatic islets, brain, heart, placenta, lungs, epididymis, salivary glands, chondrocytes, lymphocytes, and fibroblasts (24). Increased ENPPI expression inhibits the tyrosine kinase activity of the insulin receptor in several cells $(25,26)$, and causes insulin resistance $(25,27,28)$.

Several studies have demonstrated the in vitro and in vivo action of ENPPI. Increased expression of ENPPI inhibits insulin signaling in several cell types in vitro
$(26,29,30)$, and appears to be physically associated with the insulin receptor on the cell surface (26) (Figure 1).

ENPPl seems to play a role in glucose metabolism impairment in vivo. Insulin resistant rodents and humans present high levels of expression of this protein $(27,28,30,31)$. Furthermore, genetically modified mice with increased ENPPl expression in the liver and skeletal muscle show high levels of glucose and insulin, a lower degree of oral glucose tolerance, and a lower uptake of glucose in muscle (32). On the other hand, using a short hairpin RNA (shRNA) linked to an adenoviral vector to nearly completely block of ENPPl expression in the liver of $\mathrm{db} / \mathrm{db}$ mice reduced postprandial plasma glucose levels by about $30 \%$, fasting plasma glucose levels by $25 \%$, and significantly improved the oral glucose tolerance rate (33).

The pioneer study of Maddux and cols. (25) was the first to describe a rare case of extreme insulin resistance in a patient whose marked inhibition of the insulin receptor function was due to increased ENPPI expression. The deleterious effects of increased ENPP1 expression on the insulin receptor was confirmed by all subsequent studies performed on human cells $(10,26,34,35)$. Results from preclinical models involving insulin resistant, non-obese individuals without DM (thus avoiding the interference of obesity or metabolic defects resulting from hyperglycemia in ENPPI expression), enabled the elaboration of the hypothesis that the increased expression of this protein in insulin resistant humans is an early and intrinsic defect, instead of the result of secondary metabolic alterations associated with the insulin resistance state $(27,28,31)$.

\section{THE ASSOCIATION BETWEEN POLYMORPHISMS IN THE ENPP1 GENE AND INSULIN RESISTANCE, TYPE 2 DIABETES MELLITUS, OR DIABETIC NEPHROPHATY}

The gene that encodes ENPPl has 25 exons and is located on chromosome 6q22-23 (36,37) (Figure 2). This gene is regulated by glucocorticoids, agents that lead to an increase in cAMP, protein kinase $\mathrm{C}$ activator, phorbol myristate acetate, growth factors such as fibroblast growth factor, and cytokines, including IL-1 $\beta$ and TNF- $\alpha$ (revised by (24). Curiously, it appears that insulin levels regulate ENPPl expression in humans (38). However, treating cells with insulin changes the location of ENPPI from the intracellular region to the plasma membrane (39). 


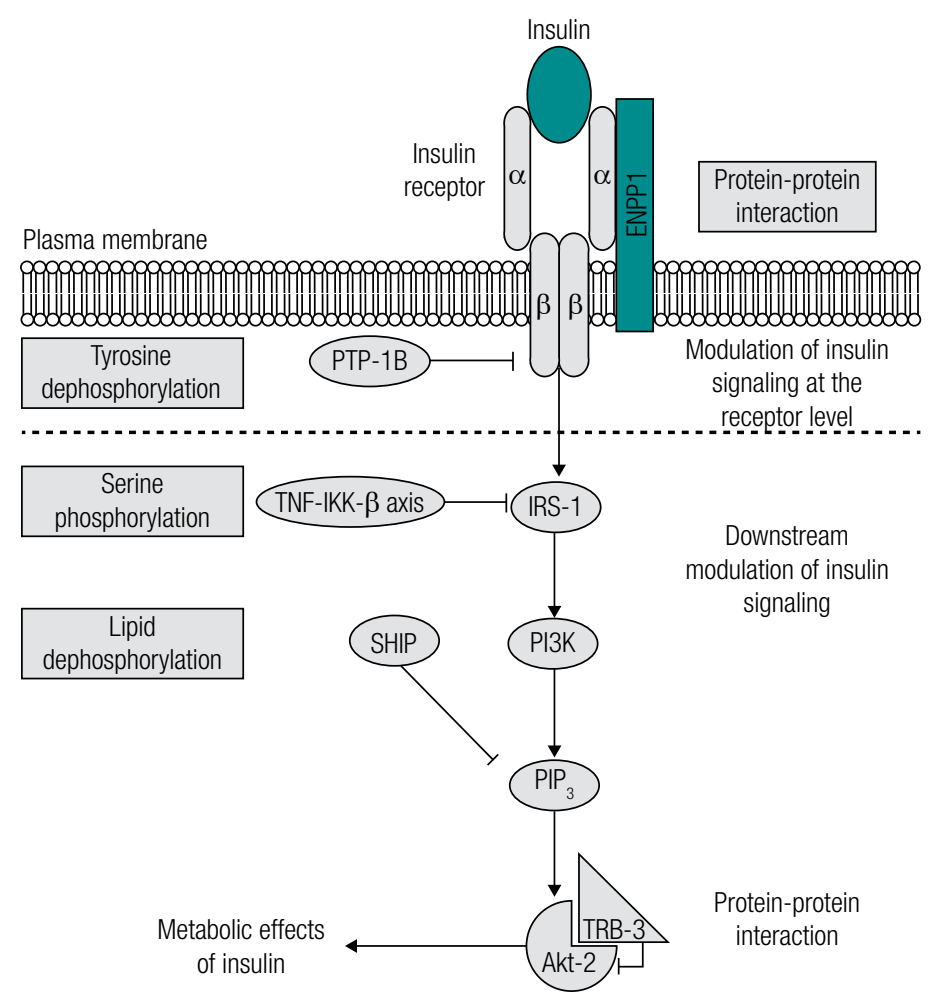

Figure 1. Systematic representation of insulin inhibitors signaling pathway with in vivo established function of insulin resistance. After binding to the $\alpha$-subunit of its receptor, insulin stimulates the signal cascade events. The most important of these events are the tyrosine residue autophosphorylation of the insulin receptor $\beta$-subunits and IRS-1, and the subsequent PI3K and Akt-2 activation. Several negative modulators of insulin signaling were described as main determinants of insulin resistance in humans; these include ENPP1, for which both post-translational and translocation to the cell surface processes are augmented by insulin signaling. The inhibitory effects of these modulators may be mediated by several mechanisms: 1) protein-protein interaction with signaling molecules, mediated by ENPP1 in the insulin receptor, and by TRB-3 in Akt-2; 2) serine residue phosphorylation of the IRS-2, mediated by TNF- $\alpha$ and IKK- $\beta$; 3) dephosphorylation of proteins with tyrosine residues phosphorylated, mediated by PTP-1B, which acts as a phosphatase in the insulin receptor; and 4) dephosphorylation of lipid substrates, mediated by SHIP, which hydrolizes the products of PI3K via its 5'-phosphatase activity. Abbreviations: Akt-2: serine-threonine kinase 2 (also known as B kinase protein); ENPP1: ecto-nucleotide pyrophosphatase/phosphodiesterase 1; IKK- $\beta$ : IkB kinase $\beta$; IRS-1: insulin receptor substrate 1; IRS-2: insulin receptor substrate 2; PI3K: phosphatidylinositol 3 kinase; PIP $_{3}$ : phosphatidylinositol 3,4,5-triphosphate; PTP-1B: protein tyrosine phosphatase 1B; TNF- $\alpha$ : tumor necrosis factor; SHIP: Src homology 2 domain containing inositol 5 phosphatase; TRB-3: mammalian tribbles homolog 3. Modified from Abate and cols. (45).

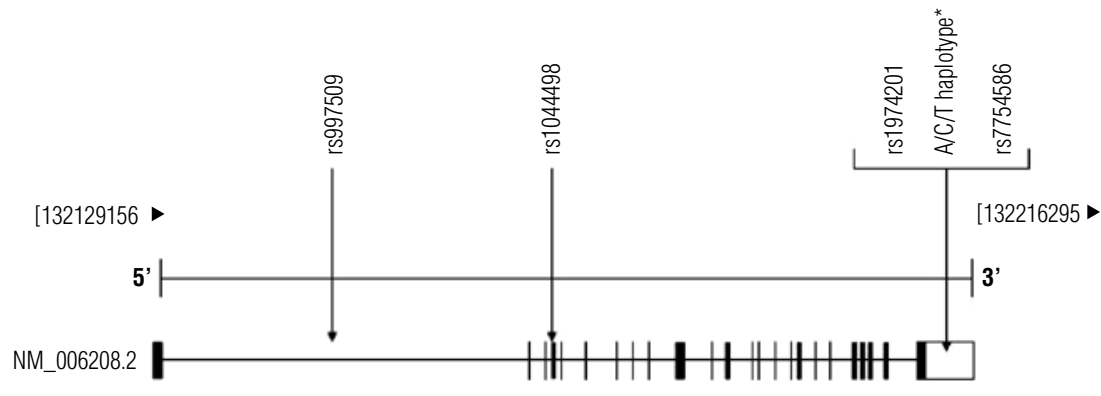

Encoding region

[ 3' UTR region

Figure 2. Map of the ENPP1 gene in chromosome 6q22-23. The 25 exons (boxes) are numbered from left to right according to the transcription region. The black boxes constitute the encoding regions, and the white box represents the 3'UTR region. Vertical arrows show the polymorphic sites associated with type 2 diabetes mellitus or diabetic nephropathy. Figure adapted from http://www.nbci.nlm.nih.gov/gene/5167. *A/C/T haplotype is constituted by 62897A, G2906C and C2948T ENPP1 polymorphisms. 
In 1999, Pizzuti and cols. (36) described a polymorphism in exon 4 of the gene ENPP1, which causes the change of the amino acid lysine $(\mathrm{K})$ to glutamine $(\mathrm{Q})$ in codon 121 (Kl21Q; rs1044498). This amino acid change is located in the second ENPPl somatomedin-B-like domain, and may interfere with protein-protein interactions (23). Non-diabetic Sicilians carrying the $Q$ variant show less insulin sensitivity than non-carriers (36). Pizzuti and cols. (36) also demonstrated that the $\mathrm{Q}$ variant of this polymorphism interacts more strongly with the insulin receptor than the $\mathrm{K}$ variant, reducing the autophosphorylation of this receptor. $\mathrm{Q}$ variant also reduces insulin-induced phosphorylation of the insulin receptor substrate l (IRS1), the kinase activity of phosphatidilinositol-3, glycogen synthesis and cell proliferation (35). Other studies confirmed the association between the K121Q polymorphism and greater insulin resistance in different populations (40-43); however, a study performed in a Danish population did not find any association between this polymorphism and markers of insulin resistance or type 2 DM (44).

It is not clear whether there is a difference in the risk for type $2 \mathrm{DM}$ among subjects who are heterozygous or homozygous for the $\mathrm{Q}$ allele of K121Q polymorphism. In fact, the low proportion of $\mathrm{Q} / \mathrm{Q}$ homozygous individuals observed in most studies (approximately $2 \%$ - $3 \%$ of the general population) does not enable appropriately testing of different genetic models (dominant, additive or recessive), due to the lack of statistical power (45).

Three meta-analyses, published in 2005 and 2006, analyzed case and control studies, and reported that although the results were not homogeneous between the studies, including thousands of adults from different ethnic groups, individuals carrying the $\mathrm{Q}$ allele of $\mathrm{K} 121 \mathrm{Q}$ polymorphism have an approximately $20 \%$ increased risk of developing type 2 DM (46-48).

Certainly, the K121Q polymorphism has been the most studied polymorphism in the ENPPI gene. Table 1 summarizes the main results of the studies that evaluated the association between the K121Q polymorphism, and DN or related characteristics.

De Cosmo and cols. (49) reported that Kl21Q polymorphism has an effect on the rate of kidney function loss in Caucasians with type $1 \mathrm{DM}$ and proteinuria. During the 6.5 years of follow-up, GFR declined faster in $\mathrm{Q}$ allele carriers $(\mathrm{QQ} / \mathrm{KQ})$ than in non-carriers. The mean decline rates were 7.2 and $3.7 \mathrm{ml} \mathrm{min}^{-1}$.year ${ }^{-1}$, respectively. With this rapid loss of kidney function,
Table 1. Studies on the association between $K 121 Q$ polymorphism in ENPP1 gene and diabetic nephropathy or associated characteristics

\begin{tabular}{|c|c|}
\hline Study population & Results \\
\hline Thai population with type 2 DM (51) & $\begin{array}{l}\text { Association between the } Q / Q \\
\text { genotype, and increased risk for DN } \\
(\mathrm{OR}=1.85 ; \mathrm{Cl} 95 \%=1.17-2.92)\end{array}$ \\
\hline $\begin{array}{l}\text { African-American population with type } \\
2 \text { DM (55) }\end{array}$ & No association with DN \\
\hline $\begin{array}{l}\text { Caucasians with type } 1 \text { DM and } \\
\text { proteinuria (49) }\end{array}$ & $\begin{array}{l}\text { Association between the } Q(K Q / Q Q) \\
\text { allele, and decline of } \mathrm{GFR}(\mathrm{OR}=5.7 \text {; } \\
\mathrm{Cl} 95 \%=4.1-7.2)\end{array}$ \\
\hline Caucasians with type 1 DM (50) & $\begin{array}{l}\text { Association between the } Q \text { allele, and } \\
\text { increased risk for ESRD }(0 \mathrm{R}=2.3 ; \mathrm{Cl} \\
95 \%=1.2-4.6)\end{array}$ \\
\hline $\begin{array}{l}\text { Italian and American populations with } \\
\text { type } 2 \text { DM (52) }\end{array}$ & $\begin{array}{l}\text { Association between the } Q \text { allele, and } \\
\text { GFR reduction in patients from } \\
\text { Gargano }(O R=1.69 ; \mathrm{Cl} 95 \%=1.1 \text { - } \\
\text { 2.6) and Boston }(0 \mathrm{R}=1.50 ; 95 \%= \\
1.0-2.2)\end{array}$ \\
\hline $\begin{array}{l}\text { Danish population with type } 1 \mathrm{DM} \\
\text { (57) }\end{array}$ & No association with DN \\
\hline $\begin{array}{l}\text { Southern Brazilian population with } \\
\text { type } 1 \text { DM (56) }\end{array}$ & No association with DN \\
\hline
\end{tabular}

Type 2 DM: type 2 diabetes mellitus; DN: diabetic nephropathy; ESRD: end-stage kidney disease; OR: odds ratio; Cl: confidence interval; GFR: glomerular filtration rate.

diabetic patients carrying the $\mathrm{Q}$ allele would progress from the proteinuria stage to ESRD in fewer years than non-carriers. Furthermore, the effects of this variant were more evident when ESRD developed earlier in the course of type I DM (49).

Canani and cols. (50), in both a case-control and a family study, investigated the association between advanced $\mathrm{DN}$ in patients with type $1 \mathrm{DM}$ and $\mathrm{Kl} 2 \mathrm{lQ}$ polymorphism frequencies. The authors reported that the $\mathrm{Q}$ variant was observed in $21.5 \%$ of the control group (without DN), $31.5 \%$ of the cases with proteinuria, and $32.2 \%$ of the cases with ESRD $(p=0.012)$. After stratification according to DM duration, the risk of developing ESRD earlier, for carriers of Q variant, was 2.3 times higher than the risk for non-carriers (CI 95\% 1.2 - 4.6). However, Q variant was not associated with late development of ESRD. Similar results were found in the familial study, using the transmission disequilibrium test.

Recently, Wu and cols. (51) also reported the association between the $\mathrm{Q}$ variant and increased risk of DN in type 2 DM patients from Taiwan. Likewise, De Cosmo and cols. (52), studying patients with type 2 DM from Gargano and Padua (Italy), and from Boston (USA), demonstrated that Q allele carriers from Gargano and Boston presented a greater risk of having a lower GFR $(\mathrm{OR}=1.69$; CI 95\%: $1.1-2.6$ and $\mathrm{OR}=$ 
1.50; CI 95\%: 1.0 - 2.2; respectively) than non-carriers. In the Padua population, results obtained showed the same trend, but did not reach formal statistical significance $(\mathrm{OR}=1.77$; CI 95\%: 0.7 - 4.5). The same group (53) analyzed a sample of type $2 \mathrm{DM}$ patients with abnormal $(20-5416 \mu \mathrm{g} / \mathrm{min})$ albumin excretion rate, and observed that patients carrying the $\mathrm{Q}$ allele presented more severe DN.

However, not all studies agree on the role of this polymorphism on $\mathrm{DN}$, suggesting that its effect may depend on the ethnic group. In fact, the $\mathrm{Q}$ (risk) allele frequency varies greatly according to the ethnic group. Q allele frequency among Brazilians of African ancestry is much higher than among those of European ancestry (54). Keene and cols. (55) studied the KI2lQ polymorphism in a sample of African-Americans with type $2 \mathrm{DM}$, but did not find a statistically significant association between this polymorphism and ESRD. These authors studied 48 other polymorphisms spread throughout ENPPI gene, and nine of them showed an association with ESRD. Leitao and cols. (54) did not find an association between K121Q polymorphism and type $2 \mathrm{DM}$ or its complications (DN or diabetic retinopathy), in a cross-sectional study performed in a Brazilian sample constituted of different ethnic groups. In a prospective, 10-year follow-up study of 30 normoalbuminuric and normotensive type $1 \mathrm{DM}$ patients from southern Brazil, de Azevedo and cols. (56), did not find an association between K121Q polymorphism, and the development of new cases of DN or diminished GFR. Jacobsen and cols. (57) did not observe any association between the K121Q polymorphism and DN progression in Danish type 1 DM patients.

The molecular mechanisms that mediate the association between the $\mathrm{Q}$ variant and the development of advanced stages of DN may only be hypothesized. As previously mentioned, ENPPl is expressed in several tissues and cell types, including mesangial and endothelial cells in the kidneys (50). These cells show progressive pathological changes throughout the evolution from normality to overt diabetic nephropathy, and it is tempting to hypothesize that ENPPl plays a role in kidney tissue damage in DN.

In vitro studies demonstrated that the ENPPI Q variant interacts more strongly with the insulin receptor than the $\mathrm{K}$ variant. Therefore, cells carrying the $\mathrm{Q}$ variant show reduced insulin receptor self-phosphorylation (36), reduced induction of the insulin receptor substrate (IRS)-1 phosphorylation, phosphatidyli- nositol 3-kinase activity, glycogen synthesis, and cell proliferation (58). Humans carrying the $\mathrm{Q}$ allele have greater insulin resistance and hyperinsulinemia than non-carriers (40). Hyperinsulinemia can stimulate the renal reabsorption of sodium, leading to volume expansion, increased sympathetic-adrenergic activity, and increased expression of angiotensin type II receptor, which hamper peripheral vasodilatation (59). Increased circulating volume and reduced peripheral vasodilatation eventually predispose to increased blood pressure and loss of the physiological nocturnal blood pressure dipping $(59,60)$, both acknowledged DN risk factors.

\section{OTHER POLYMORPHISMS IN ENPP1 GENE ASSOCIATED WITH DIABETES MELLITUS}

Meyre and cols. (61) described that a risk haplotype, constituted by three ENPPI gene polymorphisms, was associated with type $2 \mathrm{DM}$ in adults and children (total OR for adults + children = 1.58; CI 95\% $1.18-2.1$ ). This haplotype includes the Q allele of the K121Q polymorphism and two other polymorphisms in the non-encoding region (IVS20delT in the promoter region and $\mathrm{A}>\mathrm{G}+1044 \mathrm{TGA}$ in the 3'UTR region), which may possibly be involved in ENPPI gene expression. Frittitta and cols. (58) reported the association between a haplotype constituted by three polymorphisms in the $3^{\prime}$ UTR ENPPI region (G2897A, G2906C and C2948T, also called haplotype ACT), and insulin resistance and type $2 \mathrm{DM}$ (OR for type $2 \mathrm{DM}=1.69$; CI 95\% $1.01-2.83$ ).

Bochenski and cols. (62) investigated the association between seven polymorphisms and some haplotypes from a disequilibrium linkage block containing the K121Q polymorphism, and the occurrence of type $2 \mathrm{DM}$ in a Polish population controlled for obesity. In the total sample, neither type $2 \mathrm{DM}$ nor obesity were significantly associated with any of the seven polymorphisms. However, in obese subjects, the K121Q polymorphism was associated with type $2 \mathrm{DM}(\mathrm{OR}=1.6$; CI $95 \% 1.0$ - 2.6). Furthermore, T allele of polymorphism rs997509 in intron 1 was also associated with type $2 \mathrm{DM}(\mathrm{OR}=4.7$; CI 95\% 1.3 - 13.9). Interestingly, the haplotype constituted by both rs997509 T and $121 \mathrm{Q}$ alleles was the only haplotype associated with risk for type $2 \mathrm{DM}(\mathrm{OR}=4.2$; CI 95\% 1.3 - 13.5). Santoro and cols. (63), studying lean and obese children, observed that those who were carriers of the rs997509 T allele of ENPPI gene presented higher levels of plasma insulin and HOMA-IR (homeostasis model assessment 
- insulin resistance) and lower insulin sensitivity index compared with children who were homozygous for the most common allele. A similar observation was made for the Q variant of K121 polymorphism. Besides, children carrying the rare rs997509 $\mathrm{T}$ allele were at higher risk of developing metabolic syndrome and impaired glucose tolerance than children who were homozygous for the common allele. Evaluating the combined effects of polymorphisms rs 997509 and K121Q, which are in strong disequilibrium linkage, the authors demonstrated that the effect on insulin sensitivity was due to the presence of the rs997509 $\mathrm{T}$ allele and not due to the K121Q polymorphism (63).

Keene and cols. (55) genotyped 48 polymorphisms in the ENPPI gene in African-American type $2 \mathrm{DM}$ patients with ESRD (cases) or without any degree of DN (controls). Nine polymorphisms were associated with ESRD in one or more inheritance models; however, K121Q polymorphism was not one of them. The most significant associations with CKD were observed for rs7754586 and rs1974201 polymorphisms, located in the 3'UTR region or in intron 24, respectively. Furthermore, an association with CKD was found for 13 haplotypes constituted by two or more polymorphisms located on the 3'UTR region or intron 24 of the ENPPI gene.

\section{CONCLUSION}

To date, the molecular mechanisms responsible for the association between the ENPPI 121Q variant and the development of advanced stages of DN may only be hypothesized. Not all studies agree on the role of the K121Q polymorphism in the development of DN, suggesting that its effect may depend on the ethnic group. Besides, evaluating the combined effects of ENPPI rs997509 and K121Q polymorphisms, which are in strong disequilibrium linkage, some studies demonstrated that the effect on insulin sensitivity was due to the presence of the rs997509 $\mathrm{T}$ allele and not due to the presence of the K121Q polymorphism. Further studies are needed to clarify these relationships.

Disclosure: no potential conflict of interest relevant to this article was reported.

\section{REFERENCES}

1. American Diabetes Association. Diagnosis and classification of diabetes mellitus. Diabetes Care. 2009;32(1):62.
2. Gross JL, de Azevedo MJ, Silveiro SP, Canani LH, Caramori ML, Zelmanovitz T. Diabetic nephropathy: diagnosis, prevention, and treatment. Diabetes Care. 2005;28(1):164-76.

3. Carpena MP, Rados DV, Sortica DA, Souza BM, Reis AF, Canani LH, et al. Genetics of diabetic nephropathy. Arq Bras Endocrinol Metabol. 2010;54(3):253-61.

4. Marshall SM. Recent advances in diabetic nephropathy. Postgrad Med J. 2004;80(949):624-33.

5. Caramori ML, Fioretto P, Mauer M. The need for early predictors of diabetic nephropathy risk: is albumin excretion rate sufficient? Diabetes. 2000;49(9):1399-408.

6. Kramer CK, Leitao CB, Pinto LC, Silveiro SP, Gross JL, Canani LH. Clinical and laboratory profile of patients with type 2 diabetes with low glomerular filtration rate and normoalbuminuria. Diabetes Care. 2007;30(8):1998-2000.

7. Bloomgarden ZT. Diabetic nephropathy. Diabetes Care. 2008;31(4):823-7.

8. Bruno RM, Gross JL. Prognostic factors in Brazilian diabetic patients starting dialysis: a 3.6-year follow-up study. J Diabetes Complications. 2000;14(5):266-71.

9. Molitch ME, DeFronzo RA, Franz MJ, Keane WF, Mogensen CE, Parving HH. Diabetic nephropathy. Diabetes Care. 2003;26 Suppl 1:S94-8.

10. Grupe A, Alleman J, Goldfine ID, Sadick M, Stewart TA. Inhibition of insulin receptor phosphorylation by PC- 1 is not mediated by the hydrolysis of adenosine triphosphate or the generation of adenosine. J Biol Chem. 1995;270(38):22085-8.

11. Young BA, Maynard C, Boyko EJ. Racial differences in diabetic nephropathy, cardiovascular disease, and mortality in a national population of veterans. Diabetes Care. 2003;26(8):2392-9.

12. Adler Al, Stevens RJ, Manley SE, Bilous RW, Cull CA, Holman RR. Development and progression of nephropathy in type 2 diabetes: the United Kingdom Prospective Diabetes Study (UKPDS 64). Kidney Int. 2003;63(1):225-32.

13. Andersen AR, Christiansen JS, Andersen JK, Kreiner S, DeckertT. Diabetic nephropathy in Type 1 (insulin-dependent) diabetes: an epidemiological study. Diabetologia. 1983;25(6):496-501.

14. Canani LH, Gerchman F, Gross JL. Familial clustering of diabetic nephropathy in Brazilian type 2 diabetic patients. Diabetes. 1999;48(4):909-13.

15. Krolewski AS. Genetics of diabetic nephropathy: evidence for major and minor gene effects. Kidney Int. 1999;55(4):1582-96.

16. Krolewski AS, Warram JH, Rand LI, Christlieb AR, Busick EJ, Kahn CR. Risk of proliferative diabetic retinopathy in juvenile-onset type I diabetes: a 40-yr follow-up study. Diabetes Care. 1986;9(5):443-52.

17. Klein R, Klein BE, Moss SE, Davis MD, DeMets DL. The Wisconsin epidemiologic study of diabetic retinopathy. II. Prevalence and risk of diabetic retinopathy when age at diagnosis is less than 30 years. Arch Ophthalmol. 1984;102(4):520-6.

18. Canani LH, Gerchman F, Gross JL. Increased familial history of arterial hypertension, coronary heart disease, and renal disease in Brazilian type 2 diabetic patients with diabetic nephropathy. Diabetes Care. 1998;21(9):1545-50.

19. Roglic G, Colhoun HM, Stevens LK, Lemkes HH, Manes C, Fuller $\mathrm{JH}$. Parental history of hypertension and parental history of diabetes and microvascular complications in insulin-dependent diabetes mellitus: the EURODIAB IDDM Complications Study. Diabet Med. 1998;15(5):418-26.

20. Conway BR, Savage DA, Maxwell AP. Identifying genes for diabetic nephropathy--current difficulties and future directions. Nephrol Dial Transplant. 2006;21(11):3012-7.

21. Martini S, Eichinger F, Nair V, Kretzler M. Defining human diabetic nephropathy on the molecular level: integration of transcriptomic 
profiles with biological knowledge. Rev Endocr Metab Disord. 2008;9(4):267-74.

22. Freedman BI, Bostrom M, Daeihagh $P$, Bowden DW. Genetic factors in diabetic nephropathy. Clin J Am Soc Nephrol. 2007;2(6):1306-16.

23. Bollen M, Gijsbers R, Ceulemans H, Stalmans W, Stefan C. Nucleotide pyrophosphatases/phosphodiesterases on the move. Crit Rev Biochem Mol Biol. 2000;35(6):393-432.

24. Goldfine ID, Maddux BA, Youngren JF, Reaven G, Accili D, Trischitta $V$, et al. The role of membrane glycoprotein plasma cell antigen 1/ectonucleotide pyrophosphatase phosphodiesterase 1 in the pathogenesis of insulin resistance and related abnormalities. Endocr Rev. 2008;29(1):62-75.

25. Maddux BA, Sbraccia P, Kumakura S, Sasson S, Youngren J, Fisher A, et al. Membrane glycoprotein PC-1 and insulin resistance in non-insulin-dependent diabetes mellitus. Nature. 1995;373(6513):448-51.

26. Maddux BA, Goldfine ID. Membrane glycoprotein PC-1 inhibition of insulin receptor function occurs via direct interaction with the receptor alpha-subunit. Diabetes. 2000;49(1):13-9.

27. Frittitta L, Youngren JF, Sbraccia $P$, D'Adamo M, Buongiorno $A$, et al. Increased adipose tissue PC-1 protein content, but not tumour necrosis factor-alpha gene expression, is associated with a reduction of both whole body insulin sensitivity and insulin receptor tyrosine-kinase activity. Diabetologia. 1997;40(3):282-9.

28. Frittitta L, Youngren J, Vigneri R, Maddux BA, Trischitta V, Goldfine ID. PC-1 content in skeletal muscle of non-obese, non-diabetic subjects: relationship to insulin receptor tyrosine kinase and whole body insulin sensitivity. Diabetologia. 1996;39(10):1190-5.

29. Kumakura S, Maddux BA, Sung CK. Overexpression of membrane glycoprotein PC-1 can influence insulin action at a post-receptor site. J Cell Biochem. 1998;68(3):366-77.

30. Youngren JF, Maddux BA, Sasson S, Sbraccia P, Tapscott EB, Swanson MS, et al. Skeletal muscle content of membrane glycoprotein PC-1 in obesity. Relationship to muscle glucose transport. Diabetes. 1996;45(10):1324-8.

31. Frittitta $L$, Spampinato $D$, Solini $A$, Nosadini R, Goldfine ID, Vigneri $\mathrm{R}$, et al. Elevated PC-1 content in cultured skin fibroblasts correlates with decreased in vivo and in vitro insulin action in nondiabetic subjects: evidence that PC-1 may be an intrinsic factor in impaired insulin receptor signaling. Diabetes. 1998;47(7):1095-100.

32. Maddux BA, Chang YN, Accili D, McGuinness OP, Youngren JF, Goldfine ID. Overexpression of the insulin receptor inhibitor PC-1/ENPP1 induces insulin resistance and hyperglycemia. Am J Physiol Endocrinol Metab. 2006;290(4):E746-9.

33. Zhou HH, Chin CN, Wu M, Ni W, Quan S, Liu F, et al. Suppression of PC-1/ENPP-1 expression improves insulin sensitivity in vitro and in vivo. Eur J Pharmacol. 2009;616(1-3):346-52.

34. Belfiore A, Costantino A, Frasca F, Pandini G, Mineo R, Vigneri $P$, et al. Overexpression of membrane glycoprotein $\mathrm{PC}-1$ in MDA-MB231 breast cancer cells is associated with inhibition of insulin receptor tyrosine kinase activity. Mol Endocrinol. 1996;10(11):1318-26.

35. Costanzo BV, Trischitta V, Di Paola R, Spampinato D, Pizzuti A, Vigneri $R$, et al. The $Q$ allele variant (GLN121) of membrane glycoprotein PC-1 interacts with the insulin receptor and inhibits insulin signaling more effectively than the common $\mathrm{K}$ allele variant (LYS121). Diabetes. 2001;50(4):831-6.

36. Pizzuti A, Frittitta L, Argiolas A, Baratta R, Goldfine ID, Bozzali M, et al. A polymorphism (K1210) of the human glycoprotein PC-1 gene coding region is strongly associated with insulin resistance. Diabetes. 1999;48(9):1881-4.

37. Buckley MF, Loveland KA, McKinstry WJ, Garson OM, Goding JW. Plasma cell membrane glycoprotein PC-1. cDNA cloning of the human molecule, amino acid sequence, and chromosomal location. J Biol Chem. 1990;265(29):17506-11.
38. Frittitta L, Sbraccia P, Costanzo BV, Tassi V, D'Adamo M, Spampinato $D$, et al. High insulin levels do not influence PC-1 gene expression and protein content in human muscle tissue and hepatoma cells. Diabetes Metab Res Rev. 2000;16(1):26-32.

39. Menzaghi C, Di Paola R, Baj G, Funaro A, Arnulfo A, Ercolino T, et al. Insulin modulates $\mathrm{PC}-1$ processing and recruitment in cultured human cells. Am J Physiol Endocrinol Metab. 2003;284(3):E514-20.

40. Gu HF, Almgren P, Lindholm E, Frittitta L, Pizzuti A, Trischitta V, et al. Association between the human glycoprotein PC-1 gene and elevated glucose and insulin levels in a paired-sibling analysis. Diabetes. 2000;49(9):1601-3.

41. Abate N, Chandalia M. The impact of ethnicity on type 2 diabetes. J Diabetes Complications. 2003;17(1):39-58.

42. Frittitta $L$, Baratta $R$, Spampinato D, Di Paola R, Pizzuti A, Vigneri $\mathrm{R}$, et al. The $\mathrm{Q} 121 \mathrm{PC}-1$ variant and obesity have additive and independent effects in causing insulin resistance. J Clin Endocrinol Metab. 2001;86(12):5888-91.

43. Kubaszek A, Pihlajamaki J, Karhapaa P, Vauhkonen I, Laakso M. The $\mathrm{K} 1210$ polymorphism of the PC-1 gene is associated with insulin resistance but not with dyslipidemia. Diabetes Care. 2003;26(2):464-7.

44. Rasmussen SK, Urhammer SA, Pizzuti A, Echwald SM, Ekstrom $\mathrm{CT}$, Hansen L, et al. The K1210 variant of the human PC-1 gene is not associated with insulin resistance or type 2 diabetes among Danish Caucasians. Diabetes. 2000;49(9):1608-11.

45. Abate N, Chandalia M, Di Paola R, Foster DW, Grundy SM, Trischitta V. Mechanisms of disease: ectonucleotide pyrophosphatase phosphodiesterase 1 as a 'gatekeeper' of insulin receptors. Nat Clin Pract Endocrinol Metab. 2006;2(12):694-701.

46. Abate N, Chandalia M, Satija P, Adams-Huet B, Grundy SM, Sandeep S, et al. ENPP1/PC-1 K1210 polymorphism and genetic susceptibility to type 2 diabetes. Diabetes. 2005;54(4):1207-13.

47. Bacci S, Ludovico O, Prudente S, Zhang YY, Di Paola R, Mangiacotti $D$, et al. The K1210 polymorphism of the ENPP1/PC-1 gene is associated with insulin resistance/atherogenic phenotypes, including earlier onset of type 2 diabetes and myocardial infarction. Diabetes. 2005;54(10):3021-5.

48. Grarup N, Urhammer SA, Ek J, Albrechtsen A, Glumer C, Borch-Johnsen $K$, et al. Studies of the relationship between the ENPP1 K1210 polymorphism and type 2 diabetes, insulin resistance and obesity in 7,333 Danish white subjects. Diabetologia. 2006;49(9):2097-104.

49. De Cosmo S, Argiolas A, Miscio G, Thomas S, Piras GP, Trevisan R, et al. A PC-1 amino acid variant (K1210) is associated with faster progression of renal disease in patients with type 1 diabetes and albuminuria. Diabetes. 2000;49(3):521-4.

50. Canani LH, Ng DP, Smiles A, Rogus JJ, Warram JH, Krolewski AS. Polymorphism in ecto-nucleotide pyrophosphatase/phosphodiesterase 1 gene (ENPP1/PC-1) and early development of advanced diabetic nephropathy in type 1 diabetes. Diabetes. 2002;51(4):1188-93.

51. Wu LS, Hsieh $\mathrm{CH}$, Pei D, Hung YJ, Kuo SW, Lin E. Association and interaction analyses of genetic variants in ADIPOQ, ENPP1, GHSR, PPARgamma and TCF7L2 genes for diabetic nephropathy in a Taiwanese population with type 2 diabetes. Nephrol Dial Transplant. 2009;24(11):3360-6.

52. De Cosmo S, Minenna A, Zhang YY, Thompson R, Miscio G, Vedovato $M$, et al. Association of the 0121 variant of ENPP1 gene with decreased kidney function among patients with type 2 diabetes. Am J Kidney Dis. 2009;53(2):273-80.

53. De Cosmo S, Trevisan R, Dalla Vestra M, Vedovato M, Argiolas A, Solini A, et al. PC-1 amino acid variant 0121 is associated with a lower glomerular filtration rate in type 2 diabetic patients with abnormal albumin excretion rates. Diabetes Care. 2003;26(10):2898-902. 
54. Leitao CB, Nabinger GB, Krahe AL, Bolson PB, Gerchman F, Friedman $\mathrm{R}$, et al. The role of K1210 ENPP1 polymorphism in diabetes mellitus and its complications. Braz J Med Biol Res. 2008;41(3):229-34.

55. Keene KL, Mychaleckyj JC, Smith SG, LeakTS, Perlegas PS, Langefeld $C D$, et al. Association of the distal region of the ectonucleotide pyrophosphatase/phosphodiesterase 1 gene with type 2 diabetes in an African-American population enriched for nephropathy. Diabetes. 2008;57(4):1057-62.

56. de Azevedo MJ, Dalmaz CA, Caramori ML, Pecis M, Esteves JF, Maia AL, et al. ACE and PC-1 gene polymorphisms in normoalbuminuric Type 1 diabetic patients: a 10-year prospective study. $J$ Diabetes Complications. 2002;16(4):255-62.

57. Jacobsen $\mathrm{P}$, Grarup N, Tarnow L, Parving HH, Pedersen O. PC-1 amino acid variant (K1210) has no impact on progression of diabetic nephropathy in type 1 diabetic patients. Nephrol DialTransplant. 2002;17(8):1408-12.

58. Frittitta L, Ercolino T, Bozzali M, Argiolas A, Graci S, Santagati MG, et al. A cluster of three single nucleotide polymorphisms in the 3 -untranslated region of human glycoprotein PC-1 gene stabilizes PC-1 mRNA and is associated with increased PC-1 protein content and insulin resistance-related abnormalities. Diabetes. 2001;50(8):1952-5.

59. Abate N. Obesity and cardiovascular disease. Pathogenetic role of the metabolic syndrome and therapeutic implications. J Diabetes Complications. 2000;14(3):154-74.

60. McFarlane SI, Banerji M, Sowers JR. Insulin resistance and cardiovascular disease. J Clin Endocrinol Metab. 2001;86(2):713-8.

61. Meyre D, Bouatia-Naji N, Tounian A, Samson C, Lecoeur C, Vatin V, et al. Variants of ENPP1 are associated with childhood and adult obesity and increase the risk of glucose intolerance and type 2 diabetes. Nat Genet. 2005;37(8):863-7.

62. Bochenski J, Placha G, Wanic K, Malecki M, Sieradzki J, Warram $\mathrm{JH}$, et al. New polymorphism of ENPP1 (PC-1) is associated with increased risk of type 2 diabetes among obese individuals. Diabetes. 2006;55(9):2626-30.

63. Santoro N, Cirillo G, Lepore MG, Palma A, Amato A, Savarese $P$, et al. Effect of the rs997509 polymorphism on the association between ectonucleotide pyrophosphatase phosphodiesterase 1 and metabolic syndrome and impaired glucose tolerance in childhood obesity. J Clin Endocrinol Metab. 2009;94(1):300-5. 